\title{
Investigation of Health Hazards in Vehicle Refueling Stations Attendants at Malakand, Khyber Pakhtunkhwa, Pakistan
}

\author{
Imran Khan \\ Student, Department of Biotechnology, University of Malakand, Chakdara \\ Dir (Lower) Khyber Pakhtunkhwa, Pakistan \\ Tel: 92-345-937-4066_E-mail: Princeofmalakand2003@yahoo.com
}

\section{Saleem-Ur-Rahman}

M. Phil Scholar, Department of Biotechnology, University of Malakand

Chakdara, Dir (Lower), Khyber Pakhtunkhwa, Pakistan

Tel: 92-344-924-1218Ｅ-mail: saleemurrrahman20@gmail.com

Muhammad Ilyas

Student, Department of Biotechnology, University of Malakand, Chakdara

Dir (Lower) Khyber Pakhtunkhwa, Pakistan

Tel: 92-345-882-6982Ｅ-mail: Ilyasbiotech@yahoo.com

\begin{abstract}
Ayaz Ali Khan (Corresponding Author)
Assistant Professor, Department of Biotechnology, University of Malakand, Chakdara

Dir (Lower), Khyber Pakhtunkhwa, Pakistan
\end{abstract}

Tel: 92-345-886-0677Ｅ-mail: lalatejan@gmail.com

Received: December 29, 2012 Accepted: January 10, 2013

doi:10.5296/jbls.v4i1.2960 URL: http://dx.doi.org/10.5296/jbls.v4i1.2960 


\begin{abstract}
Vehicles refueling station workers are a class of labors prone to long term petroleum product toxicity due to their routine work at vehicles refueling stations. Health problems posed by the pollutants at the work environment of an individual are closely linked to the nature and level of exposure to these hazardous chemicals. The adverse effect of the toxicants in such environment is a common phenomenon in all the developing countries. The awareness about this problem is lacking in Pakistan, particularly in Khyber Pakhtunkhwa. In present study, blood biochemical parameters like calcium, cholesterol, glucose, magnesium, potassium, phosphorus and triglyceride levels were determined among workers and control individuals. The results of the workers showed an increase in glucose, cholesterol and phosphorus level; while significant decrease was observed in calcium and potassium level as compared to the control group of individuals. While the level of magnesium and triglyceride level was same in both groups. In comparative picture, the blood biochemical parameters were normal in control as that of workers. Further study may be conducted to investigate the effect of such environment on other blood parameters and large size population may be included in the study.
\end{abstract}

Keywords: Blood chemistry, Vehicle Refueling Stations, Hazardous chemicals

\title{
1. Introduction
}

Vehicles refueling station workers are a class of labors prone to long term petroleum product toxicity due to their routine work at vehicles refueling stations (Hobson, 1984). Petrol diesel products affect different systems of the body (Niazi et al., 1989) because of the presence of organic and inorganic substances (Kilburn, 2000). Paraffin's, naphthalene's, and aromatics are the three groups of crude oil (Hobson, 1984). In addition to the practically infinite mixtures of hydrocarbon compounds that form crude oil, sulfur, nitrogen, and oxygen are usually present in small but often important quantities (Krewski et al., 2000). Sodium chloride and many metallic elements are found in crude oils, among them the most common are vanadium and nickel; which are potent carcinogenic and mutagenic (Mildvan, 1970). Transporting the oil can affect the wildlife, environment and can pollute groundwater. Processing oil at the refinery can contribute to air and water pollution. Diesel exhausts produce pollutants like hydrocarbons, oxides of nitrogen and carbon (Ware et al., 1993). Burning gas online to fuel cars contributes to air pollution which can alter lung function (Salvi et al., 1999).Health problems posed by these pollutants at the work environment of an individual are closely linked to the nature and level of exposure to these hazardous chemicals, whose exposure; can create symptoms like chronic cough, wheezing and breathlessness (Ware et al., 1993).

The adverse effects of the toxicants in such environment, is a common phenomenon in all the developing countries. The awareness about this problem is lacking in Pakistan, particularly in Khyber Pakhtunkhwa. Therefore, the present study is focused to investigate, the effects of vehicles refueling stations environment on health status of the workers, and to recommend guidelines in case of ill effects, that will be helpful in safety measures.

\section{Materials and Methods}

\subsection{Study Design and Data Collection}


A survey of the study area was conducted in April-August 2009, during which, primary data and blood samples were collected from the workers of different vehicles refueling stations and the people living all around the area near the vehicles refueling stations (control). A total of 50 individuals were randomly selected for the study irrespective of their age and working hours in the station. A printed questionnaire regarding the age, socioeconomic status, and health status; narcotic using habit and duration of stay at work place was completed by each participant before the blood sample was collected after written informed consent. University of Malakand ethical committee approved the study protocol. Furthermore, these two groups were further subdivided into two groups on the basis of their ages (20-30 years and 30-40 years age groups).

\subsection{Blood Collection}

All the individuals were not informed prior to sampling; therefore, all the individuals were in non-fasting condition. The blood samples of $3 \mathrm{ml}$ were collected from each person in tubes and after 30 minutes, the collected samples were centrifuged at $6000 \mathrm{rpm}$ for 2 minutes for serum separation. The collected serum was used for analysis of various biochemical tests. Fully Automatic Blood Chemistry Analyzer 4000 (Italy) and Shimadzu Double Beam Spectrophotometer 1700 Pharma (Japan) was used for analysis of different biochemical parameters.

\subsection{Biochemical Analysis}

The following biochemical parameters were measured in order to study the effect of vehicles refueling stations on the health status of workers.

\subsubsection{Calcium Level}

The calcium level was determined in the serum using the method and principle described by Pollard and Martin, (1956) and Gitelman, (1967).

\subsubsection{Cholesterol}

The esterified cholesterol is hydrolyzed into free cholesterol and then into cholestene-3-one with formation of hydrogen peroxide that reacts with hydroxybenzoate and 4 aminoantipyrine to produce a colored complex whose color intensity is directly proportional to the total cholesterol (Trinder et al., 1969 and Kaplan et al., 1989).

\subsubsection{Glucose}

The glucose level is determined in the presence of glucose oxidase, formed hydrogen peroxide that reacts with phenol and 1-aminophenazone to red violet quantifiable as indicator (Barham et al., 1972 and Teuscher et al., 1971).

\subsubsection{Magnesium}

The photometric determination of magnesium was carried out by using the Calorimetric endpoint method described by Bablok et al., 1988. The color intensity was determined photometrically in the ultra violet region $(340 \mathrm{~nm})$.

\subsubsection{Potassium}


The amount of potassium was determined by using sodium tetraphenylboron in a specifically prepared mixture - method documented by Hilmann et al., (1967) and Henry, (1974).

\subsubsection{Triglycerides}

The triglyceride level was determined after the enzymatic hydrolysis with lipases. Indicator was quinonemine, formed of hydrogen peroxide, 4-amino antipyrine and 4-chlorophenol, under the catalytic influence of peroxidase - a principle described by Jacobs and VanDemark, (1960).

\subsection{Data Analysis}

Data obtained was statistically analyzed by using online available software, Prism, Demo version 05, downloaded from the site www.graphpad.com.

\section{Results}

\subsection{History of Workers and Control}

A printed questionnaire was designed to collect the information regarding the age, socioeconomic status, narcotic use and health status of workers and their total duration at stations, as well as from the control group (Table 1).

Table 1. History of workers and control

$\mathrm{TB}=$ Tuberculosis

\begin{tabular}{|c|c|c|c|c|c|c|}
\hline $\begin{array}{l}\text { Age Group } \\
\text { (Years) }\end{array}$ & $\begin{array}{c}\text { No. } \\
\text { Sample }\end{array}$ & $\begin{array}{c}\text { Economic } \\
\text { Status }\end{array}$ & $\begin{array}{l}\text { Feeding } \\
\text { Condition }\end{array}$ & $\begin{array}{l}\text { Health } \\
\text { Status \% }\end{array}$ & $\begin{array}{l}\text { Narcotic } \\
\text { Users \% }\end{array}$ & $\begin{array}{l}\text { Exposure Time } \\
\text { (Months) }\end{array}$ \\
\hline \multicolumn{7}{|l|}{ Workers } \\
\hline$(20-30)$ & 30 & Poor & Non Fasting & $\begin{array}{l}\text { 2Chest Pain } \\
2 \text { Allergy } \\
1 \text { TB } \\
9 \text { Fatigued }\end{array}$ & $\begin{array}{l}1 \text { Snuff } \\
2 \text { Cigarettes } \\
0 \text { Hashish }\end{array}$ & $12-80$ \\
\hline $30-40$ & 20 & Poor & Non Fasting & $\begin{array}{l}\text { 4Chest Pain } \\
3 \text { Allergy } \\
2 \text { TB } \\
14 \text { Fatigued }\end{array}$ & $\begin{array}{l}2 \text { Snuff } \\
2 \text { Cigarettes } \\
1 \text { Hashish }\end{array}$ & $36-204$ \\
\hline $\begin{array}{l}\text { Control } \\
(20-30)\end{array}$ & 30 & Poor & Non Fasting & $\begin{array}{l}\text { 0Chest Pain } \\
0 \text { Allergy } \\
0 \text { TB } \\
1 \text { Fatigued }\end{array}$ & $\begin{array}{l}2 \text { Snuff } \\
1 \text { Cigarettes } \\
0 \text { Hashish }\end{array}$ & 00 \\
\hline$(30-40)$ & 20 & Poor & Non Fasting & $\begin{array}{l}\text { 0Chest Pain } \\
1 \text { Allergy } \\
0 \text { TB } \\
3 \text { Fatigued }\end{array}$ & $\begin{array}{l}1 \text { Snuff } \\
1 \text { Cigarettes } \\
0 \text { Hashish }\end{array}$ & 00 \\
\hline
\end{tabular}

\subsection{Analysis of Calcium Level}

Calcium level of the vehicles refueling station workers and control was analyzed to study the effect of petroleum on blood calcium. The mean level of calcium for vehicles refueling stations workers was $(6.92 \pm 0.56 \mathrm{mg} / \mathrm{dl}, P$ value $=0.1136)$ with a range of $(9.1 \pm 0.49$ to $2.5 \pm 1.1 \mathrm{mg} / \mathrm{dl})$. 


\section{Macrothink}

The mean level of calcium for the control was $(8.42 \pm 0.90 \mathrm{mg} / \mathrm{dl}, P$ value $=0.1136)$ with a range of $(11.7 \pm 2.73$ to1.45 $\pm 0.29 \mathrm{mg} / \mathrm{dl})$. The calcium level was low in vehicles refueling station workers when compared to that of control group. Graphs showing mean calcium level of control and vehicles refueling station workers have been given in figure no.01. The calculated $P$ value for calcium was 0.1136 , while the level of significance was 0.05 . The $P$ value 0.1136 was greater than the level of significance $(0.05)$.

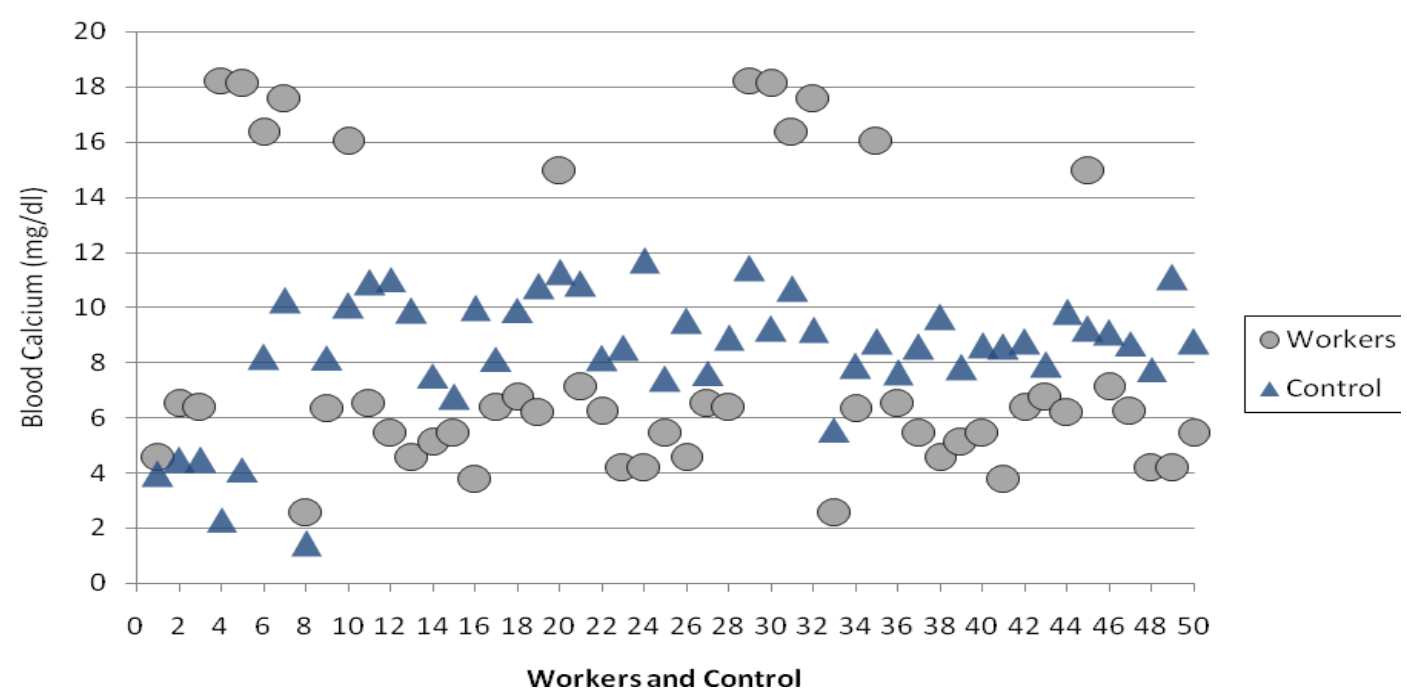

Figure 1.The calcium level of the workers and control individuals

\subsection{Analysis of Cholesterol level}

The mean value of cholesterol level for vehicles refueling station workers was $(166.05 \pm 3.66$ $\mathrm{mg} / \mathrm{dl}, P$ value $=<0.0325$ ) with a range of $80.33 \pm 5.93$ to $317 \pm 2.00 \mathrm{mg} / \mathrm{dl}$. The mean value of cholesterol for control was $(148.09 \pm 0.397 \mathrm{mg} / \mathrm{dl}, P$ value $=<0.0325)$ with a range of $(146.9 \pm$ 0.387 to $169.1 \pm 0.788 \mathrm{mg} / \mathrm{dl}$ ). In figure 02 , the graph has been given, showing the mean cholesterol level of control and vehicles refueling station workers. The $P$ value for cholesterol was calculated $<0.0325$ while the level of significance was 0.05 .

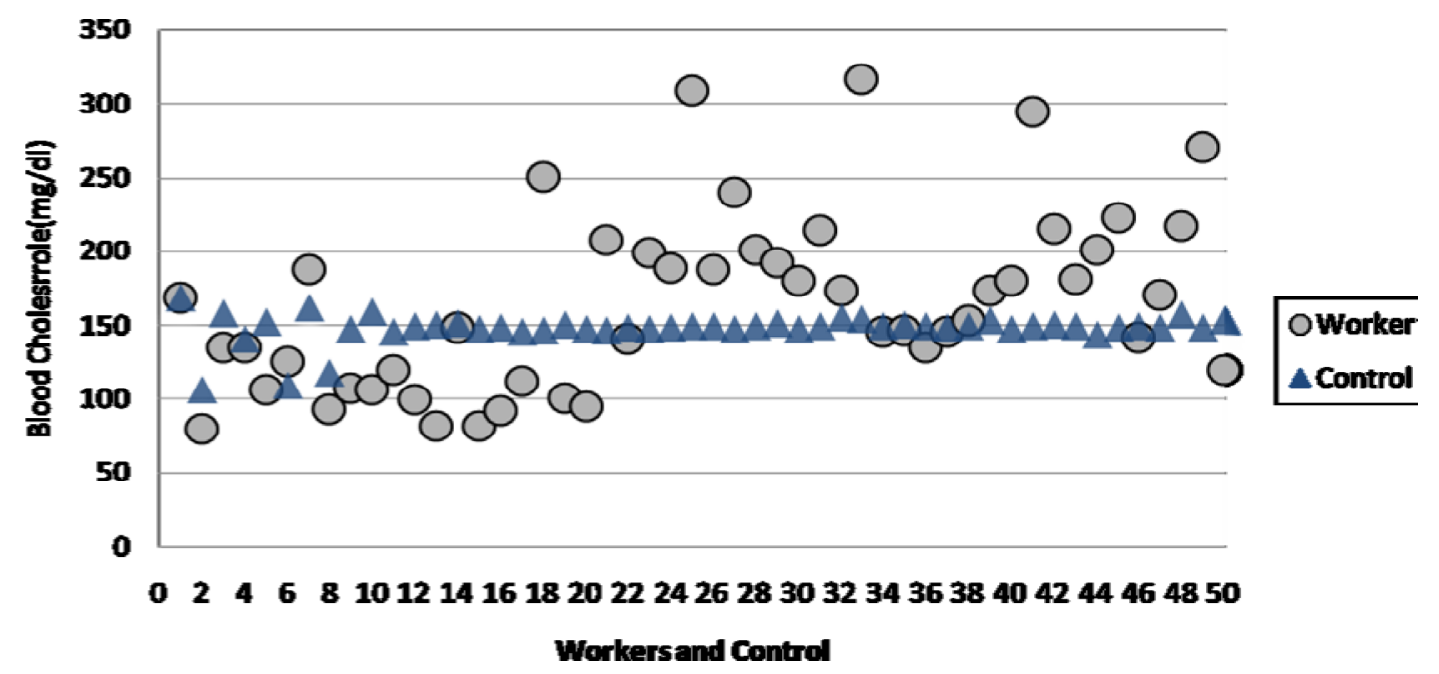

Figure 2. The cholesterol level of the workers and control individuals 


\section{MInstitute Macrothink $_{\text {Int }}$}

\subsection{Analysis of Glucose}

The mean value of glucose for workers was $(142.7 \pm 2.5 \mathrm{mg} / \mathrm{dl}, P$ value $=0.0213)$ with a range of $64.3 \pm 3.01$ to $280.33 \pm 3.512 \mathrm{mg} / \mathrm{dl}$. The mean value for control was $(103.33 \pm 2.08 \mathrm{mg} / \mathrm{dl}$, $P$ value $=0.0213$ ) with a range of $73.00 \pm 2.08$ to $124.33 \pm 2.5 \mathrm{mg} / \mathrm{dl}$. Graphical presentation of mean glucose level of control and workers has been made in figure no. 03. The $P$ value for glucose was calculated 0.0213 while the level of significance was 0.05 .

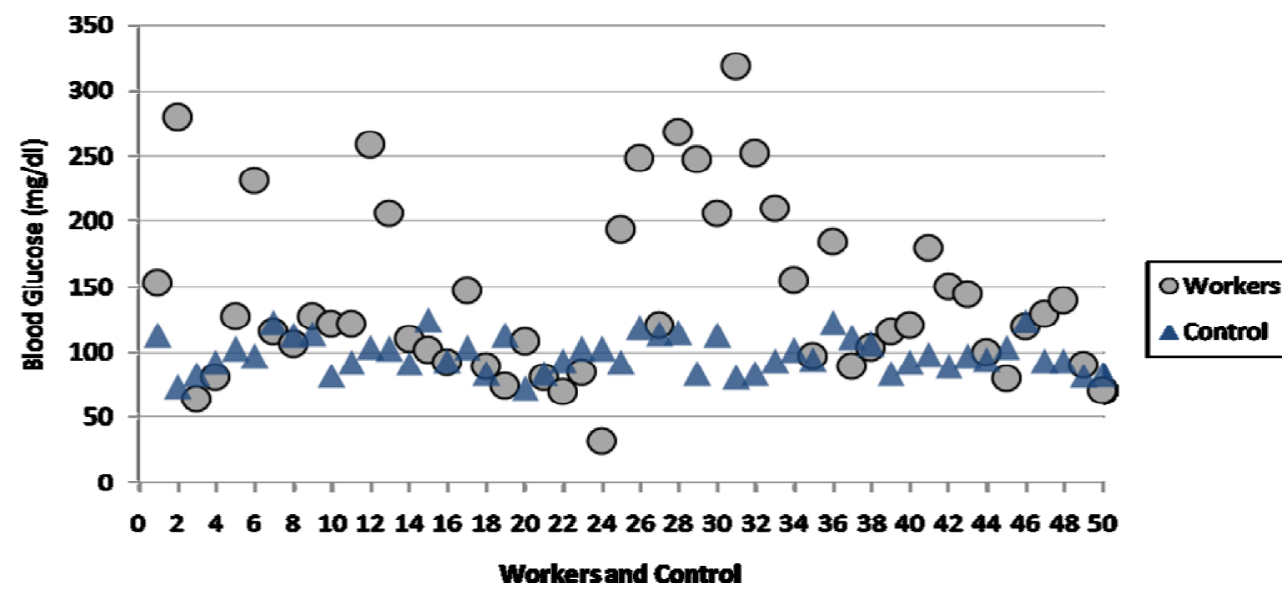

Figure 3. The blood glucose level of the workers and control individuals

\subsection{Analysis of Magnesium level}

Magnesium level of vehicles refueling station workers and control was analyzed using UV spectrophotometer. The mean value for magnesium level of workers was $(2.3 \pm 0.27 \mathrm{mg} / \mathrm{dl}, P$ value $=0.0057$ ) with a range of $0.83 \pm 0.045$ to $4.33 \pm 0.07 \mathrm{mg} / \mathrm{dl}$. The mean value for magnesium level of control was $(1.92 \pm 0.082 \mathrm{mg} / \mathrm{dl}, P$ value $=0.0057)$ with a range of $1.487 \pm$ 0.075 to $2.087 \pm 0.035 \mathrm{mg} / \mathrm{dl}$. Vehicle refueling environment has no significant effect on the magnesium level of the workers. Graph showing mean magnesium level of control and workers has been given in figure no. 04 . The $P$ value for magnesium was calculated 0.0057 while the level of significance was 0.05 .

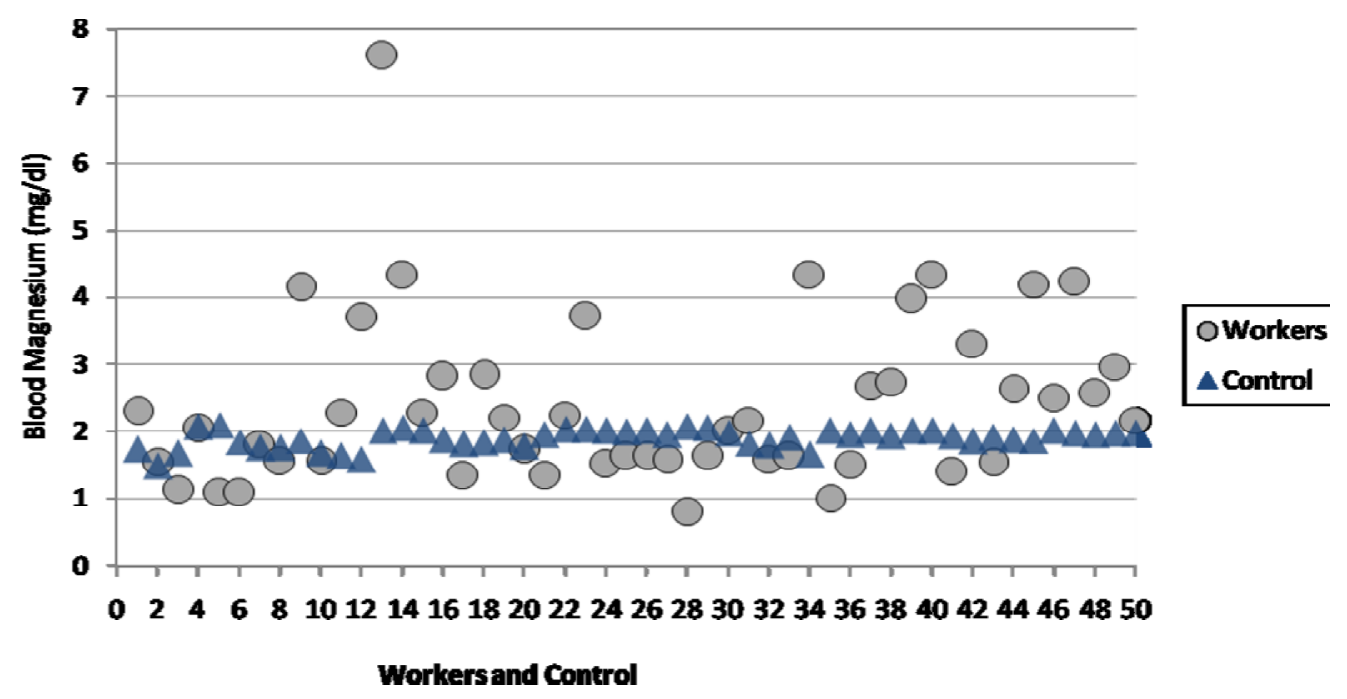

Figure 4. The Magnesium level of the workers and control individuals 


\section{MInstitute Macrothink}

\subsection{Analysis of Phosphorus level}

Mean value for phosphorus level of workers was $(8.6 \pm 2.32 \mathrm{mg} / \mathrm{dl}, P$ value $=0.0150)$ with a range of $1.02 \pm 0.230$ to $8.6 \pm 2.32 \mathrm{mg} / \mathrm{dl}$. Mean value for phosphorus level of control group was $(4.937 \pm 0.076 \mathrm{mg} / \mathrm{dl}, P$ value $)$ with a range up to $4.7 \pm 0.087$ to $5.180 \pm 0.060 \mathrm{mg} / \mathrm{dl}$. A significant increase in blood phosphorous level was detected in workers exposed to vehicle refueling station environment when compared with control group $(P$ value $=0.0150)$. Graph showing mean phosphorus level of workers and control has been given in figure no 05 . The $P$ value for phosphorus was calculated 0.0150 and the level of significance was 0.05 .

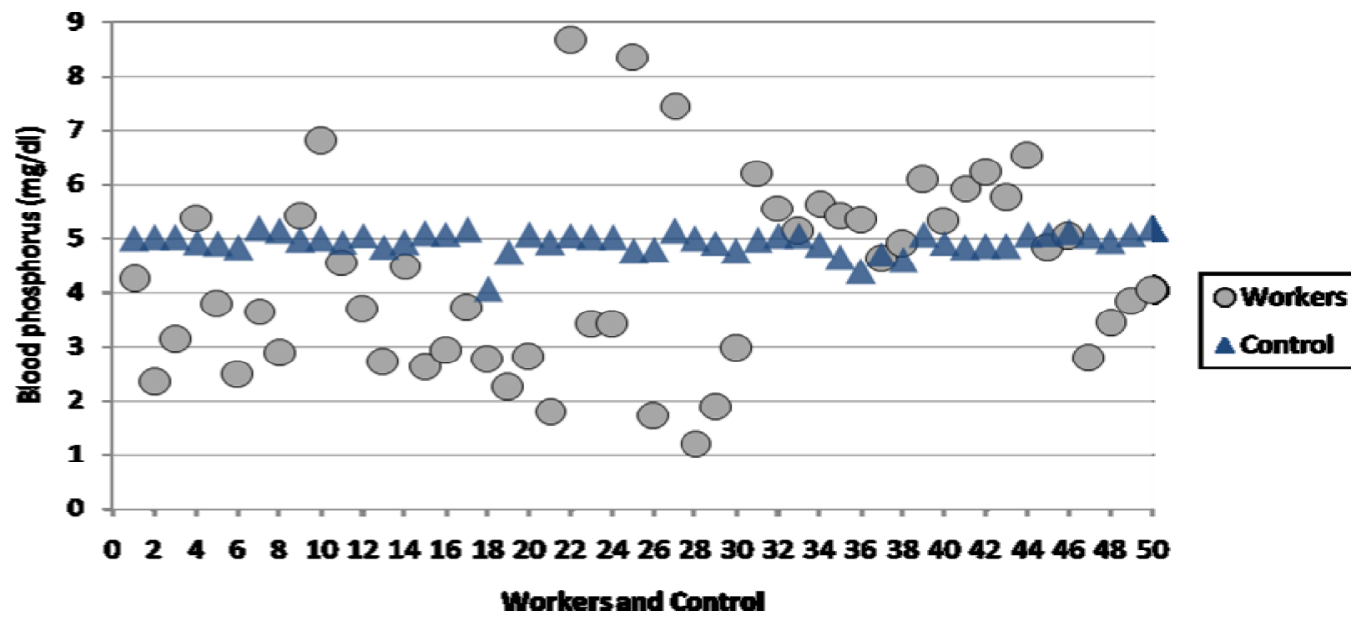

Figure 5. The phosphorus level of the workers and control individuals

\subsection{Analysis of Potassium level}

Mean value for potassium level of workers was $(1.73 \pm 0.36 \mathrm{mg} / \mathrm{dl}$, P value $=0.0331)$ with a range of $0.65 \pm 0.04$ to $8.5 \pm 1.5 \mathrm{mg} / \mathrm{dl}$. Mean value for potassium level of control group was $(3.14 \pm 0.111 \mathrm{mg} / \mathrm{dl}, P$ value $=0.0331)$ with a range up to $1.33 \pm 0.16$ to $4.9 \pm 0.11 \mathrm{mg} / \mathrm{dl}$. The potassium level of workers was less than that of control, which showed that exposure to such environment, may decrease the blood potassium level of workers. Graph showing mean potassium of control and workers has been given in figure no. 06. The $P$ value for potassium was calculated 0.0331 and the level of significance was 0.05 .

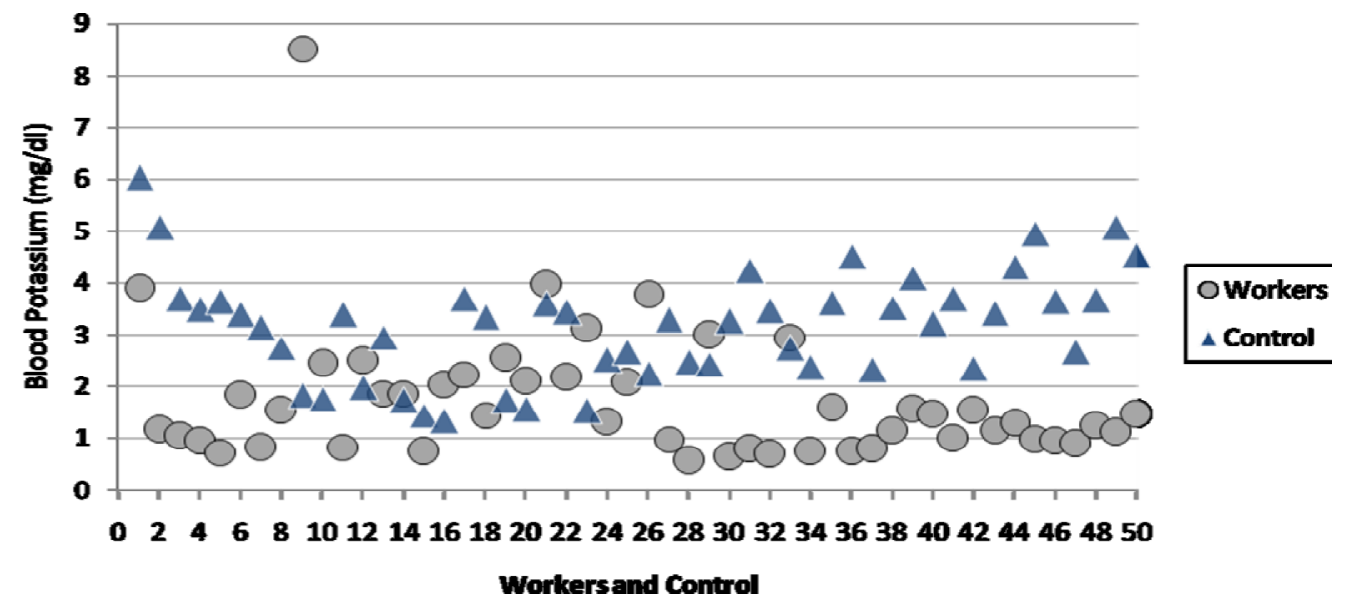

Figure 6. The blood potassium level of the workers and control individuals 


\subsection{Analysis of Triglyceride level}

Mean value for triglycerides level of workers was $(167.5 \pm 5.1 \mathrm{mg} / \mathrm{dl}, P$ value $=<0.0012)$ with a range of $35.6 \pm 5.5$ to $288.03 \pm 3.01 \mathrm{mg} / \mathrm{dl}$. Mean value for triglycerides level of control group was $(147.4 \pm 3.86 \mathrm{mg} / \mathrm{dl}, P$ value $=<<0.0012)$ with a range of $109.9 \pm 0.202$ to $178.8 \pm 0.563$ $\mathrm{mg} / \mathrm{dl}$. There is no significant difference between triglyceride level of workers and that of control, which shows that, exposure to petroleum may have no effect on blood triglycerides level of workers. Graphs showing mean triglycerides of control and workers have been given in figure no. 07. The $P$ value for triglycerides was calculated $<0.0012$ and the level of significance was 0.05 .

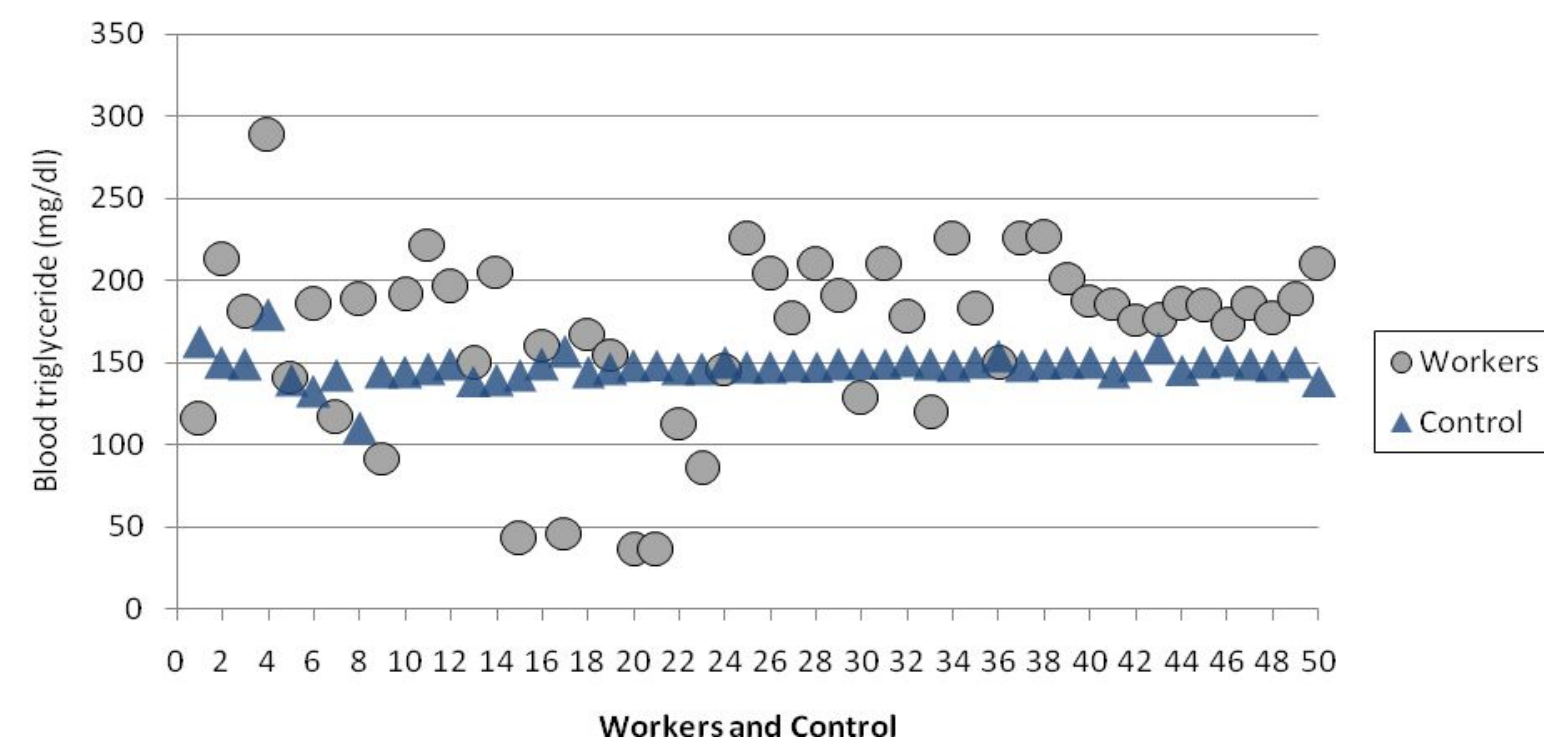

Figure 7. The blood triglyceride level of the workers and control individuals

\subsection{Comparative Analysis of Blood Chemistry of Workers and Control Individuals}

The comparison has also been made among the worker's and control's blood chemical parameters, and also age wise comparison of different blood chemical parameters among control and workers has been sorted out. These have been shown in table no. 02 and 03 respectively.

Table 2. Comparative analysis of blood chemistry of workers and control individuals

\begin{tabular}{|l|cccccc|}
\hline \multicolumn{1}{|c|}{ Parameters } & \multicolumn{3}{c|}{ Workers } & \multicolumn{3}{c|}{ Control } \\
\hline & Mean \pm SD & $p$ & $95 \%$ C.I & Mean \pm SD & $p$ & 95\% C.I \\
& & & & & & \\
& & & & & \\
Calcium $(\mathrm{mg} / \mathrm{dl})$ & $6.92 \pm 0.56$ & 0.1136 & -2.6 to 0.29 & 0.901 & 0.1136 & -2.6 to 0.29 \\
Cholesterol $(\mathrm{mg} / \mathrm{dl})$ & $166.05 \pm 3.66$ & 0.0325 & -34 to -15 & $148.09 \pm 0.397$ & 0.0325 & -34 to -15 \\
Glucose $(\mathrm{mg} / \mathrm{dl})$ & $142.7 \pm 2.5$ & 0.0213 & 16 to 62 & $103.33 \pm 2.080$ & 0.0213 & 16 to 62 \\
Magnesium $(\mathrm{mg} / \mathrm{dl})$ & $2.3 \pm 0.27$ & 0.0057 & -0.87 to -0.16 & $1.92 \pm 0.082$ & 0.0057 & -0.87 to -0.16 \\
Phosphorus $(\mathrm{mg} / \mathrm{dl})$ & $8.6 \pm 2.32$ & 0.0150 & 0.13 to 1.1 & $4.937 \pm 0.076$ & 0.0150 & 0.13 to 1.1 \\
Potassium $(\mathrm{mg} / \mathrm{dl})$ & $1.73 \pm 0.36$ & 0.0331 & -20 to -0.89 & $3.14 \pm 0.111$ & 0.0331 & -20 to -0.89 \\
Triglyceride $(\mathrm{mg} / \mathrm{dl})$ & $167.5 \pm 5.1$ & 0.0012 & 4.4 to 35 & $147.4 \pm 3.86$ & 0.0012 & 4.4 to 35 \\
\hline
\end{tabular}

$\mathrm{SD}=$ Standard Deviation, C.I= Confidence Interval 
Table 3. Age wise comparative analysis of blood chemistry of workers and control individuals

\begin{tabular}{|c|c|c|c|c|c|c|c|}
\hline Parameters & $\begin{array}{l}\text { Calcium } \\
(\mathrm{mg} / \mathrm{dl})\end{array}$ & $\begin{array}{l}\text { Cholesterol } \\
\qquad(\mathrm{mg} / \mathrm{dl})\end{array}$ & $\begin{array}{c}\text { Glucose } \\
(\mathrm{mg} / \mathrm{dl})\end{array}$ & $\begin{array}{l}\text { Iagnesium } \\
\qquad(\mathrm{mg} / \mathrm{dl})\end{array}$ & $\begin{array}{l}\text { hosphorus } \\
\text { (mg/dl) }\end{array}$ & $\begin{array}{l}\text { Potassium Trig } \\
(\mathrm{mg} / \mathrm{dl})\end{array}$ & $\begin{array}{l}\text { glyceride } \\
(\mathrm{mg} / \mathrm{dl})\end{array}$ \\
\hline \multicolumn{8}{|l|}{$\begin{array}{l}\text { Workers } \\
\text { Age Group } \\
(20-30)\end{array}$} \\
\hline Mean \pm SD & $8.615 \pm 5.394$ & $149.4 \pm 57.99$ & $42.7 \pm 69.85$ & $2.251 \pm 1.358$ & $3.775 \pm 1.908$ & $2.093 \pm 1.561$ & $153.5 \pm 62.55$ \\
\hline Lower & 2.560 & 80.30 & 32.33 & 0.800 & 1.210 & 0.570 & 35.67 \\
\hline Upper & 18.23 & 309.5 & 280.2 & 7.600 & 8.660 & 8.530 & 288.1 \\
\hline \multicolumn{8}{|l|}{$\begin{array}{l}\text { Workers } \\
\text { Age Group } \\
(30-40)\end{array}$} \\
\hline Mean \pm SD & $7.545 \pm 4.604$ & $191.1 \pm 54.01$ & $142.8 \pm 61.88$ & $2.670 \pm 1.085$ & $5.126 \pm 0.988$ & $1.201 \pm 0.508$ & $187.2 \pm 25.46$ \\
\hline Lower & 2.560 & 119.6 & 71.00 & 1.000 & 2.780 & 0.690 & 119.2 \\
\hline Upper & 17.56 & 317.0 & 319.0 & 4.330 & 6.530 & 2.960 & 225.9 \\
\hline \multicolumn{8}{|l|}{$\begin{array}{l}\text { Age Group } \\
(20-30)\end{array}$} \\
\hline Mean \pm SD & $8.240 \pm 2.797$ & $146.5 \pm 13.10$ & $100.1 \pm 14.44$ & $1.888 \pm 0.161$ & $4.948 \pm 0.2048$ & $2.853 \pm 1.079$ & $9 \quad 146.3 \pm 10.58$ \\
\hline Lower & 1.460 & 106.7 & 73.00 & 1.490 & 4.070 & 1.330 & 109.9 \\
\hline Upper & 11.70 & 169.2 & 125.0 & 2.090 & 5.180 & 6.050 & 178.8 \\
\hline \multicolumn{8}{|l|}{$\begin{array}{l}\text { Age Group } \\
(30-40)\end{array}$} \\
\hline Mean \pm SD & $8.712 \pm 1.177$ & $150.4 \pm 2.975$ & $96.68 \pm 12.40$ & $0 \quad 1.926 \pm .0898$ & $4.920 \pm 0.200$ & $0 \quad 3.621 \pm 0.836$ & $6 \quad 149.2 \pm 3.776$ \\
\hline Lower & 5.580 & 144.2 & 81.00 & 1.660 & 4.400 & 2.330 & 138.8 \\
\hline Upper & 11.10 & 157.2 & 124.3 & 2.020 & 5.180 & 5.070 & 158.9 \\
\hline
\end{tabular}




\section{Discussion}

A questionnaire was designed to collect the information about the age, economic status, and health status and exposure time of the workers to petroleum. The workers were of different age groups ranging from 20-40 years. All the workers had poor economic status. Among the workers, $16 \%$ were narcotics users. They used different kinds of narcotics including snuff, cigarettes and hashish etc. The information about their health status revealed that $12 \%$ of workers had chest pains, 10\% had allergies and 6\% had TB (Tuberculosis). Most of the workers were suffering from muscular pain and fatigue. All of them were having full time duty. Control group had also allergy as well as muscular fatigue. All the individuals were in non fasting state. The blood samples were collected randomly. The serum samples of the workers were analyzed for calcium level. The mean level of calcium for workers was $(6.92 \pm 0.56$ $\mathrm{mg} / \mathrm{dl})$. The calcium level was low in vehicles refueling station workers when compared to that of control group. The difference between the two groups might be due to exposure of the workers to vehicle refueling station environment. Same results have been found by Shakirov (2001), by mentioning that calcium level was low in the workers engaged in oil refueling industry. From the present result of calcium, and after the comparison with the previous research work done on the same aspect, it is revealed that the exposure to such environment leads to decrease in blood calcium level. The reason may be that lead is added to petroleum as anti knocking agent and it has adverse effect on calcium level. Lead increases the mobility of calcium to come out from the bones and enters into the blood stream. There will be the high level of calcium in blood and elimination from the body leads to deficiency of calcium(hypocalcemia). The mean value for cholesterol level of the workers was $(166.05 \pm$ $3.66 \mathrm{mg} / \mathrm{dl}$ ), which represents high cholesterol level that might be exposure to petroleum environment. The present study is in correlation with the study of Tsai et al., (2009) in which a positive association between several health risk factors and mortality was recorded. The present study is not in correlation with the study of Raza et al., (1995), who reported a decreased cholesterol level in workers exposed to gasoline. The deviation from the study cited may be due to the exposure time of the workers, difference in sample sizes or subject; or exposure to other chemicals present in the environment. The high level of cholesterol may be due to the leaded petroleum which has positive co-relation with each other. Lead alters the cholesterol level. When lead level increases, cholesterol level also rises up. The mean value for glucose level of workers was $(142.7 \pm 2.5 \mathrm{mg} / \mathrm{dl})$. The mean value for glucose level of control was $(103.33 \pm 2.082 \mathrm{mg} / \mathrm{dl})$. The results showed that there is significant increase in glucose level of workers. Increase glucose level in petrochemical industry workers has also been reported by Pollini et al., (1986), which is in co-relation with the present findings. The present study is also in agreement with the study of Tsai et al., (2009), who reported an increased level of glucose in petroleum industry population. The present study is not in correlation with Alonso-Alvarez et al., (2007), who found a reduced glucose level after acute exposure to heavy fuel oil in seabird. The deviation may be due to exposure time, or may be also due to differences in experimental subjects. Mean value for Magnesium level of workers was $(2.3 \pm$ $0.27 \mathrm{mg} / \mathrm{dl}$ and for control group was $(1.92 \pm 0.082 \mathrm{mg} / \mathrm{dl})$. The results showed that there was no significant difference among the two groups. The present study is not in correlation with the study of Shakirov (2001), by observing an increased level of magnesium in workers engaged in 
oil refining industry. The present study is also not in correlation with the study of Katsumiti et al., (2009). This deviation may be due to certain factors like exposure time of the workers in the environment, experimental subject, chemicals and equipment used in evaluation of magnesium level. The mean value of Phosphorus for workers was $(8.6 \pm 2.32 \mathrm{mg} / \mathrm{dl})$ and for control was $(4.937 \pm 0.076 \mathrm{mg} / \mathrm{dl} \mathrm{dl})$. Phosphorus level of workers was high as compared to control. The present study is in correlation with the study of Shakirov (2001), that workers, who had been exposed to oil-refining industry showed a remarkable increase in phosphorus level among all exposed workers. The mean value of potassium for workers was $(1.73 \pm 0.36 \mathrm{mg} / \mathrm{dl})$ and for control was $(3.14 \pm 0.111 \mathrm{mg} / \mathrm{dl})$. Potassium level of workers was low as compared to control. The present study is in correlation with the study of Brauner et al., (1999). Workers, who had been exposed to crude oil, were examined and decrease in Potassium level was found among exposed workers. The present study is also in agreement with the study of Shakirov (2001), who examined the electrolyte metabolism in workers engaged in oil-refining industry. The mean value of triglycerides for workers was $(167.5 \pm 5.1 \mathrm{mg} / \mathrm{dl})$ and for control was $(147.4 \pm$ $3.86 \mathrm{mg} / \mathrm{dl})$. From the present results it was concluded that there was no any significant difference among the two groups ( $\mathrm{P}$ Value $=<0.0125$ ). The present study is not in correlation with the study of Raza et al., (1995) by detecting decreased blood triglycerides level after exposure of workers to gasoline. The deviation from the study cited may be due to difference in exposure time of the workers, difference in sample sizes or subject, or exposure to other chemicals present in the environment.

\section{Conclusion}

From the present study it was concluded that vehicle refueling station environment have adverse effects on health status of workers. Biochemical tests (calcium, cholesterol, glucose, magnesium, potassium, phosphorous and triglycerides) of workers showed that such environment have ill effects on workers' health. Glucose, cholesterol and phosphorous level of workers were high and there was a decrease in calcium and potassium level. Exposure of workers to such environment may cause bone deformity due to effect on calcium and phosphorous level, as well as, can also cause heart problem due to high cholesterol level. Increased glucose level may lead to diabetes. These ill effects are due to lack of safety measures, poor hygiene and lack of basic health education.

\section{Limitations}

Limitations of the present study are, small population size was studied, and, the compounds present in the petroleum products were not measured in the workers due to lack of facilities.

\section{References}

Alonso-Alvarez, C., Pérez, C., \& Velando, A. (2007). Effects of acute exposure to heavy fuel oil from the Prestige spill on a seabird. Aquatic Toxicology, 15, 84(1), 103-10. http://dx.doi.org/10.1016/j.aquatox.2007.06.004

Bablok, W., Passing, H., Bender, R., \& Schneider, B. (1988). A general regression procedure for method transformation. Journal of Clinical Chemistry and Clinical Biochemistry, 26, 783-790. 
Braham, D., \& Trinder, P. (1972). Methods for determination of blood glucose level by spectrophotometer. Analyst, 97-142.

Brauner, C. J., Ballantyne, C. L., Vijayan, M. M., \& Val, A. L. (1999). Crude oil exposure affects air-breathing frequency, blood phosphate levels and ion regulation in an air-breathing teleost fish, Hoplosternumlittorale. Comparative Biochemistry and Physiology - Part C: $\begin{array}{llll}\text { Toxicology \& Pharmacology, } & 123(2), & 127-34 .\end{array}$ http://dx.doi.org/10.1016/S0742-8413(99)00018-3

Gitleman, H. (1956). Analytical Biochemistry, 18- 521.

Henry, R. J., Cannon, D. C., \& Winkleman, J. W. (1974).Clinical Chemistry: Principles and Techniques. $2^{\text {nd }}$ Edition, Harper \& Row, Maryland, 664-646.

Hillmann, G., \& Beyer, G. Z. (1967). Klinische Biochemie, 5, 93-94.

Hobson, G. D. (1984). Modern petroleum technology.Edi. $5^{\text {th }} ; 2$; ISBN 0-471-26249-8.

Jacobs, N. J., \& Vandemark, P. J. (1960). The purification and properties of the alpha-glycerophosphate-oxidizing enzyme of Streptococcus faecalis 10C1. Archives of Biochemistry and Biophysics, 88, 250-255. http://dx.doi.org/10.1016/0003-9861(60)90230-7

Kaplan, L. A., and Pesce, A. J. (1989). Procedures for the collection of arterial blood specimens: Approved Standard. Edi $3^{\text {rd }}$, Clinical Chemistry, Mooby Ed. NCCLS Document.

Katsumiti, A.,Domingos, F. X., Azevedo, M., Dasilva, M. D., Damian, R. C., Almeida, M. I., Deassis, H. C., Cestari, M. M.,Randi, M. A., Ribeiro, C. A., \& Freire, C. A. (2009). An assessment of acute biomarker responses in the demersal catfish Cathoropsspixii after the Vicuna oil spill in a harbour estuarine area in Southern Brazil. Environmental Monitering Assessment, 152, 209-222. http://dx.doi.org/10.1007/s10661-008-0309-3

Khan, A. A., Inam, S., Idrees, M., Dad, A., Gul, K., \& Akbar, H. (2010). Effect of automobile workshop on the health status of auto mechanics in N. W. F. P., Pakistan. African Journal of Environmental Science and Technology, 4(4), 192-200. http://dx.doi.org/10.5897/AJEST09.234

Kilburn, K. H. (2000). Effect of diesel exhaust neurobehavioral and pulmonary function. Environmental Health; 55, 11-17. http://dx.doi.org/10.1080/00039890009603379

Krewski, D., Snyder, R., Beatty, P., Granville, G., Meek, B., \& Sonawane, B. (2000).Assessing the health risk of benzene: A report on the benzene state of the science workshops. Journal of Toxicology and Environmental Health, 61, 307-338. PMID: 11086936 http://dx.doi.org/10.1080/00984100050166325

Mildvan, A. S. (1970). Metals in enzymes catalysis. In: The enzymes, Vol. II (Ed: D.D.Boyer). Academic Press, London; pp. 445-536.

Niazi, G. A., Flemming, A. F., \& Siziya, S. (1989). Blood dyscrasia in unofficials vendors of petrol and heavy oil and motor mechanics in Nigeria. Tropical Doctor, 19(2), 55-58. 
Pollard, F. H., \& Marun, J. V. (1956). Analyst, 81-348.

Pollini, G., Maugeri, U., Tringali, S., Jedrychowski, W., \& Flak, E. (1986). Prevalence of hypertension and cardiovascular risk factors in workers of petrochemical industry, The Pavia Study. GiornaleItaliano Di Medicina Del Lavoro, 8(3-4), 89-108. PMID: 3452560

Raza, H., Qureshi, M. M., \& Montague, W. (1995). Alteration of glutathione, glutathione S-transferase and lipid peroxidation in mouse skin and extracutaneous tissues after topical application of gasoline. International Journal of Biochemistry and Cell Biology, 27(3), 271-7. PMID: 7780831 http://dx.doi.org/10.1016/1357-2725(95)93663-I

Salvi, S., Blomberg, A., Ruddel, B., Kelly, F., Sandstorm, T., Holgate S. T., \& Frew A. (1999). Acute inflammatory responses in the air ways and peripheral blood after short-term exposure to diesel exhaust in volunteers. American Journal of Respiratory and Critical Care Medicine, 159, 702-709.

Shakirov, D. F. (2001). Electrolyte metabolism in workers engaged in oil-refining industry. Gigiena I Sanitariia, 3, 49-52. PMID: 11519463

Teuscher, A., \& Richterich, P.(1971). Enzymatic method of glucose. Schweizerische Medizinische Wochenschrift, 101, 345- 390.

Trinder, P. (1969). Determination of Glucose in Blood Using Glucose Oxidase with an Alternative Oxygen Acceptor. Annual Clinical Biochemistry, 6, 24-25.

Tsai, S. P., Bhojani, F. A., \& Wendt, J. K. (2009). Combined impact of health risk factors on mortality of a petroleum industry population. Journal of Occupational and Environmental Medicine, 51(8), 916-21. http://dx.doi.org/10.1097/JOM.0b013e3181ab59b0

Ware, J. H., Spengler, J. D., Neas, L. M., Samet, J. M., Wagner, G.R., Coultas, D., Ozkaynak, H., \& Schwab M.(1993). Respiratory and irritant health effect of ambient volatile organic compounds. American Journal of Epidemiology, 137(12), 1287-1301. PMID: 8333411

\section{Copyright Disclaimer}

Copyright reserved by the author(s).

This article is an open-access article distributed under the terms and conditions of the Creative Commons Attribution license (http://creativecommons.org/licenses/by/3.0/). 